\title{
Conservation-based breeding program design for genetic improvement in Gumz sheep in the western lowlands of Ethiopia
}

Y. Dagnew ${ }^{1,2^{*}}$, M. Urge ${ }^{2}$, Y. Tadesse ${ }^{2}$ and S. Gizaw ${ }^{3}$

\begin{abstract}
Background: Genetic improvement in livestock in developing countries like Ethiopia remains challenging; selectionbased breeding schemes have the potential to provide resource-poor producers with access to improved animals that could ensure increased productivity of animals and hence contribute to reduced poverty. Therefore, the aim of this study was to compare alternative breeding program designs to improve productivity of Gumz sheep for sustainable utilization and conservation of genetic resource. In this paper, two village-based and two central nucleus-based sheep breeding schemes were modeled and evaluated in terms of their biological and economic efficiencies. The schemes were scheme-1: a village-based breeding scheme with existing lambing, scheme-2: a village-based scheme with improved lambing, scheme-3: central nucleus-based scheme with 5\% nucleus size and scheme-4: central nucleus-based scheme with 10\% nucleus size.

Results: The annual genetic gains per year in 6-month weight $(\mathrm{kg})$ were differed across schemes and ranged from 0.154 to 0.171 in village-based scheme, and 0.334 to 0.336 in central-based schemes. The annual genetic gain per year in number of lambs born per ewe bred ranged from 0.0017 to $0.0036 \%$ in both village- and central nucleus-based scheme. The genetic gain in the proportion of lambs weaned per ewe was comparable across central nucleus-based scheme but little differed in village-based schemes and ranged from 0.0015 to $0.0016 \%$.

Conclusion: Central nucleus-based schemes resulted in the highest genetic gain and economic efficiencies in all breeding objectives compared to village-based schemes. However, this scheme requires establishing a very large central nucleus flocks. Village-based scheme with estrous synchronization was the best option. The expected genetic gains and profits were higher as it promotes participation of farmers and achieving concentrated lambing which in turn increase selection intensity and genetic progress. This suggested the possibility for sustainable Gumz sheep improvement and conservation through village-based schemes and estrous synchronization.
\end{abstract}

Keywords: Conservation, Nucleus breeding, Sheep, Smallholder farmer, Village breeding

\section{Background}

Sheep production is an important component of livestock sector to address food insecurity and reduce poverty among smallholder farmers in the developing countries like Ethiopia. Because of their unique adaptation to marginal environments with low level of input, indigenous

\footnotetext{
*Correspondence: yohanesdagnew@yahoo.com

${ }^{2}$ School of Animal and Range Sciences, College of Agriculture and Environmental Science, Haramaya University, PO Box 138, Dire Dawa, Ethiopia

Full list of author information is available at the end of the article
}

sheep contributes much for sustaining rural livelihoods by producing a wide range of products. They provide cash income, food (meat and milk), skin and manure for their keepers. They also serve as a means of risk mitigation during crop failures and monitory saving in addition to their sociocultural and ceremonial purposes $[1$, 2]. The demand for sheep mutton has increased due to increased human population and urbanization. Importance of sheep in the national economy of Ethiopia was also boosted by both domestic and international markets. Ethiopia possess many adapted indigenous sheep 
breeds, which are important components of smallholder livestock production systems in Ethiopia [3, 4]. The sheep population of the country is diverse consisting of about 14 sheep types in six major groups and nine breeds [5].

Northwestern lowland of Amhara region is among the potential areas in livestock production and consequently in the supply of live animals to the Sudan market [6]. This offers an opportunity for farmers to increase their income by timely supplying and targeting appropriate market. This shows that sheep production could be one potential source for employment opportunity to alleviate poverty in the country. Therefore, the rising demand for live sheep or sheep product in and outside the country will necessitate producing market-oriented sheep breed through improvement in the current inefficient sheep production and marketing systems in the country.

The Gumz sheep breed, on which this study focused, is one of the indigenous sheep breed distributed in the western and northwestern lowlands of Ethiopia [7, 8]. Gumz sheep is resistant to disease with better survival rate, while having a substantial economic, social and cultural importance [7]. Gumz sheep are also superior in most of the reproductive traits as compared to the Rutana sheep breed [9]. However, it has lower growth performance and body weights compared to the exotic Rutana sheep. Rutana sheep was introduced from the Sudan due to its fast growth rate and big body size. These characteristics make the Rutana sheep and their crossbreds to be economically more important and have been influencing the farmers' opinions toward the Gumz sheep.

Even though, Gumz sheep breed is highly prolific and adaptable to the hot environmental condition, farmers are more interested in Rutana sheep and their crossbreds. However, this is seriously threatening the existence of indigenous Gumz sheep breed. Reports indicated that the population size of Gumz breed is declining [5]. Hence, the current drive for rapid livestock development through crossbreeding and the threat status of indigenous sheep [10] requires research to design and implement suitable breeding strategies so as to improve productivity and conserve indigenous breeds.

Lack of effective, sustainable breeding programs for local breeds is one reason that such breeds lose their competitive advantage, especially where production systems or external conditions are subject to change [11]. Conservation of Gumz sheep genetic resources could be imperative as these have been ensuring most to sheep genetic diversity in Ethiopia and reduce poverty among smallholder farmers. This requires optimal breeding program to conserve and improve productivity of Gumz sheep. Given the current harsh production circumstances and the potential of Gumz sheep to meet future changes in production conditions and production goals, the useful functional and adaptive traits provided by indigenous Gumz sheep could be secured through development of conservation-based breeding programs. The objective of this study was to compare alternative breeding program designs to improve productivity of Gumz sheep for sustainable utilization and conservation of genetic resource.

\section{Methods \\ Study areas}

The study was conducted in Metema and Quara districts of the Amhara Regional State of Ethiopia. Metema and Quara districts were purposively selected based on distribution of Gumz, Rutana and their crossbred's sheep breeds. Metema district is located at $900 \mathrm{~km}$ northwest of Addis Ababa and at $180 \mathrm{~km}$ west of Gondar. It has an altitude range of 550-1680 masl, mean range temperature of $22-43^{\circ} \mathrm{C}$ and mean range annual rainfall of 850 $1100 \mathrm{~mm}[7,12]$. Quara district is located at $1123 \mathrm{~km}$ northwest of Addis Ababa and $324 \mathrm{~km}$ southwest of Gondar. The district is situated at an altitude ranging from 528 to 654 masl. The mean annual rainfall of the area ranges from about $600 \mathrm{~mm}$ to around $1200 \mathrm{~mm}$ while the average daily temperature is $31^{\circ} \mathrm{C}$ with ranges from 19.2 to $41.1{ }^{\circ} \mathrm{C}$ minimum and maximum temperature, respectively [13] (Fig. 1).

\section{Description of production and breeding system of Gumz sheep}

The existed production system, production objective, breeding management, infrastructure and other relevant information were studied using participatory approaches [14]. A brief account of production system and breeding management obtained from the previous survey results is summarized below. A detailed description of production system is given in article published earlier [14].

Northwestern lowland of Amhara region is among the potential areas in livestock production and consequently in the supply of live animals for both domestic and export market (Sudan market) [6, 12]. Cattle, goat, sheep and donkey were the livestock species reared by smallholder farmers. The study area is characterized as a subsistenceoriented and low-input extensive production system. The smallholder farmers possess small size of livestock number mainly relays on family labor.

The most important sheep breeds reared in the study areas were the indigenous Gumz and the introduced Rutana sheep breed. In addition, there was a crossbred sheep between Gumz and Rutana sheep. The smallholder farmers primarily keep the indigenous Gumz sheep followed by the crossbreds. As reported earlier [14], Gumz sheep are kept under low-input and low-output production system. Gumz sheep have multipurpose functions and supporting the livelihoods of smallholder farmers 


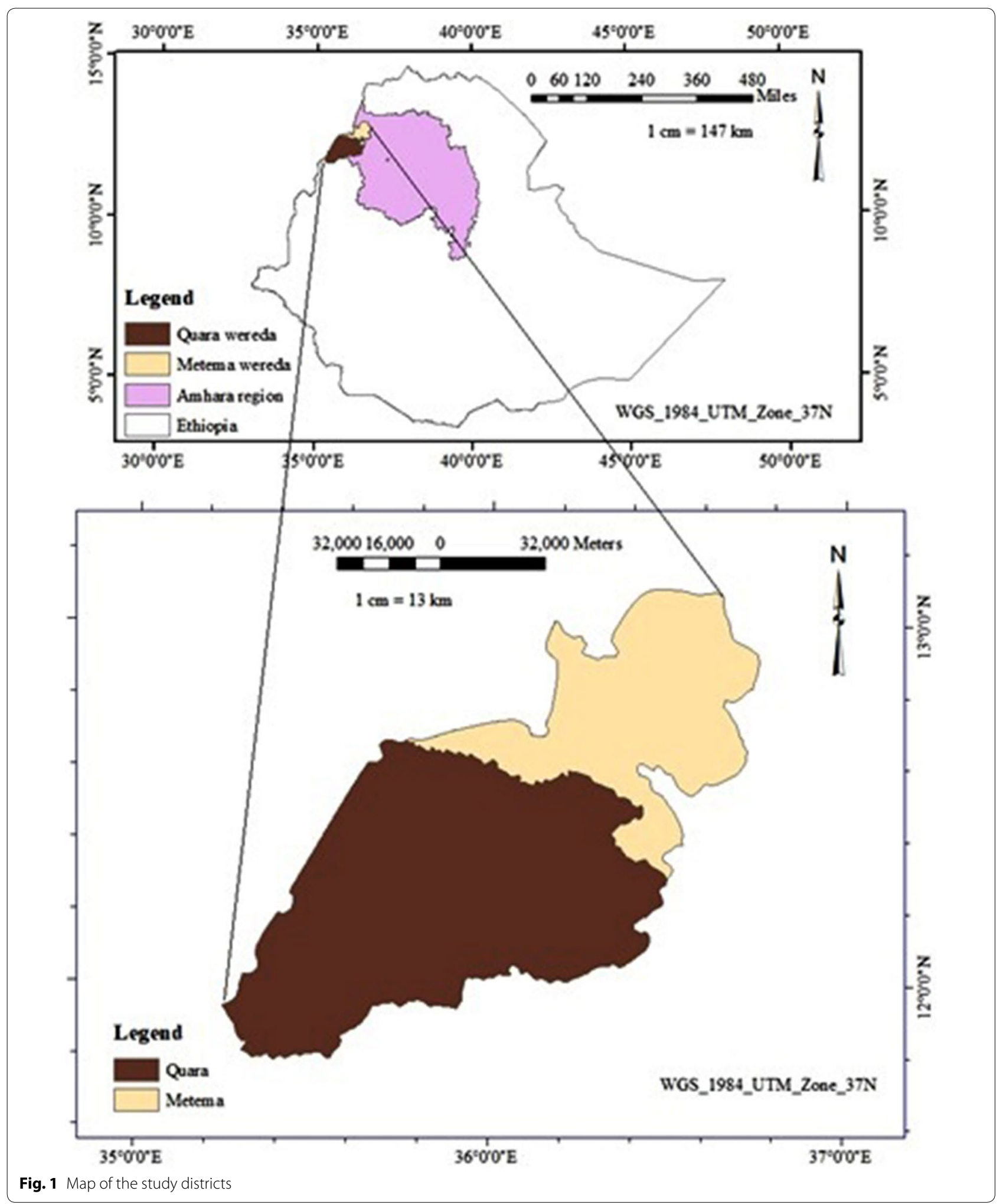


by being financial and food source [14]. The typical flock sizes were small, male animals are either sold or slaughtered and their number remains small in the flock. The major type of herding practiced in the study areas was free grazing. Smallholder farmers herd sheep either together with goat or separately depending on the availability of hired labor. As reported by the farmers, diseases, labor shortage, stock theft, feed shortage and predator were the most important limiting factors for the sheep production in the area. Since farmers live with low level of education, there is no performance or pedigree recording. The involvement of other stakeholders in genetic improvement in local indigenous sheep genotype was very minimal.

\section{Breeding goal and selection criteria}

The Gumz sheep farmers breeding goal required for the design were generated from previous studies $[7,14]$. The breeding-objective traits identified included 6-month weight (SWT), pre-weaning lamb survival (PWS) and litter size (LTS). Bio-economic models were constructed on Microsoft Excel spreadsheet to derive economic values of traits, considering both tangible and intangible benefits of rearing Menz sheep [15]. The Menz sheep-relative economic weight in previous studies was adopted for the current simulation study. The relative economic weights for SWT, PWS and LTS are presented in Table 2.

\section{Selection of villages and alternative designs of breeding schemes}

Multistage stratified sampling was employed to select kebeles purposively based on sheep breed distribution, sheep population and accessibility. Three kebeles were selected from each district representing smallholder production systems. Accordingly, a total of six kebeles (three from each district) representing smallholder systems were selected.

The villages/kebeles with the highest concentration of pure Gumz sheep in each district were selected to introduce the breeding program. The selection was based on the previous flock inventory results taken from each kebele/villages, secondary data from the district agriculture and rural development office, focus group discussions held with key informants, village leaders, researchers and livestock experts in the area. The criteria employed were high Gumz sheep possession, presence of communal grazing land in the villages, accessibility and willingness of the community in the village to participate in the breeding strategy.

A total of 14,057 sheep and ewes of 7591 were monitored from data available from the kebeles/villages. The breeding program was designed to serve this population. Six villages from Metema district (Shinfa, Kokit, Tumet,
Achera, Agam-wuha and Kumer-afitete) and eight villages from Quara district (Bambawe, Bermile, Mehaded, Diza-Gumz, Kozera, Seliferedi, Daza and Kuza) were taken. Those kebeles/villages were selected purposely to trace the exact breeding tract of Gumz sheep.

Two main schemes were proposed for evaluating optimal breeding program: These were village-based schemes (scheme 1-2) and central nucleus-based schemes (scheme 3-4) which are being implemented by the Amhara Agricultural Research Institute (ARARI). Both schemes are being increasingly advocated for traditional production systems [16]. Each of the villagebased and central nucleus-based schemes was evaluated under two scenarios: The schemes identified were villagebased schemes (schemes 1-2) and central nucleus-based schemes (scheme 3-4; Table 1). The village-based scheme is supposed to be established in each cooperative breeding village, whereas the central nucleus-based scheme with one central nucleus flock is designed to address the whole Gumz sheep population in the selected villages. The four alternative schemes were simulated using ZPLAN computer program [17] developed for this purpose deterministically. The four alternative schemes are described below:

Scheme-1: village-based scheme with existing lambing distribution over a year. The distribution of lambing was recorded from a monitoring study (Fig. 2). Lambs born during the peak lambing season between July and September were considered to be available for selection every year. The whole village sheep population is involved in selection. The villagers select breeding rams from across all the flocks in the village taken as one big breeding flock and use the selected rams communally. The traditional year-round distribution of lambing could result in low selection intensity.

Scheme-2: Village-based scheme with improved lambing distribution: Through improved breeding management and estrous synchronization, it would be possible to concentrate lambing within a short period of time. The scheme was modeled with about $85 \%$ of the lambing to take place within a short period of time.

Scheme-3: A central nucleus-based scheme with 5\% nucleus size: Scheme- 3 is modeled with a nucleus size of $5 \%$ of the total population of ewes. A possible opennucleus breeding scheme for the indigenous Gumz sheep consisting of a total of 360 breeding ewes and 15 rams. There will be 10 nucleus flocks and each nucleus flock will consist of 36 breeding ewes. The top $5 \%$ of the rams will be selected as the future sires for the nucleus flocks. The second top sires will be distributed to flocks of smallholder farmers participating in the breeding strategy project. 
Table 1 Population, biological and economic parameters for four alternative breeding schemes for Gumz sheep

\begin{tabular}{|c|c|c|c|c|}
\hline & \multicolumn{2}{|c|}{$\begin{array}{l}\text { Village-based } \\
\text { schemes }\end{array}$} & \multicolumn{2}{|c|}{$\begin{array}{l}\text { Central nucleus- } \\
\text { based schemes }\end{array}$} \\
\hline & Scheme-1 & Scheme-2 & Scheme-3 & Scheme-4 \\
\hline \multicolumn{5}{|l|}{$\begin{array}{l}\text { Proportion of popula- } \\
\text { tions in }\end{array}$} \\
\hline Production unit & 1.0 & 1.0 & 0.95 & 0.90 \\
\hline Central nuclei & & & 0.05 & 0.10 \\
\hline $\begin{array}{l}\text { Proportion of ewes } \\
\text { lambing }\end{array}$ & 0.48 & 0.80 & - & - \\
\hline \multicolumn{5}{|l|}{$\begin{array}{l}\text { Lifetime use (years) } \\
\text { of: }\end{array}$} \\
\hline $\begin{array}{l}\text { Rams in central } \\
\text { nucleus }\end{array}$ & - & - & 0.67 & 0.67 \\
\hline Rams in villages & 2.5 & 2.5 & 2.5 & 2.5 \\
\hline $\begin{array}{l}\text { Ewes in central } \\
\text { nucleus }\end{array}$ & & & 5 & 5 \\
\hline Ewes in villages & 5.0 & 5.0 & 5 & 5 \\
\hline $\begin{array}{l}\text { Mating ratio (F/M) - } \\
\text { villages }\end{array}$ & 35 & 35 & 35 & 35 \\
\hline $\begin{array}{l}\text { Mating ratio-central } \\
\text { nucleus }\end{array}$ & - & - & 35 & 35 \\
\hline $\begin{array}{l}\text { Lambing interval } \\
\text { (years) }\end{array}$ & 0.60 & 0.60 & 0.60 & 0.60 \\
\hline $\begin{array}{l}\text { Conception rate- } \\
\text { central nucleus }\end{array}$ & - & - & 0.85 & 0.85 \\
\hline $\begin{array}{l}\text { Conception rate- } \\
\text { villages }\end{array}$ & 0.85 & 0.85 & 0.85 & 0.85 \\
\hline $\begin{array}{l}\text { Age at first lambing } \\
\text { (years) }\end{array}$ & 1.14 & 1.14 & 1.14 & 1.14 \\
\hline Twinning rate & 1.32 & 1.32 & 1.32 & 1.32 \\
\hline $\begin{array}{l}\text { Survival of rams - vil- } \\
\text { lages }\end{array}$ & 0.85 & 0.85 & 0.85 & 0.85 \\
\hline $\begin{array}{l}\text { Survival of rams- } \\
\text { central nucleus }\end{array}$ & - & - & 0.85 & 0.85 \\
\hline $\begin{array}{l}\text { Survival of ewes—vil- } \\
\text { lages }\end{array}$ & 0.85 & 0.85 & 0.85 & 0.85 \\
\hline $\begin{array}{l}\text { Survival of ewes- } \\
\text { central nucleus }\end{array}$ & - & - & 0.85 & 0.85 \\
\hline $\begin{array}{l}\text { Lamb weaning } \\
\text { rate—village }\end{array}$ & 0.85 & 0.85 & 0.85 & 0.85 \\
\hline $\begin{array}{l}\text { Weaning rate-cen- } \\
\text { tral nucleus }\end{array}$ & - & - & 0.90 & 0.90 \\
\hline $\begin{array}{l}\text { Suitability for } \\
\text { breeding }^{\mathrm{a}}\end{array}$ & 0.90 & 0.90 & 0.90 & 0.90 \\
\hline $\begin{array}{l}\text { Fixed costs per ewe } \\
\text { (Birr) }\end{array}$ & 12.0 & 12.0 & 158.9 & 158.9 \\
\hline $\begin{array}{l}\text { Variable costs per } \\
\text { ewe (Birr) }\end{array}$ & 12.05 & 12.05 & 11.37 & 11.37 \\
\hline
\end{tabular}

a Proportion of proven selection candidates physically suitable for breeding

Scheme-4: A central nucleus-based scheme with 10\% of nucleus size: Same as scheme-3, but the scheme was consisting of a total of 720 breeding ewes and 30 rams. Ewes will be divided into 10 flocks of 72 ewes/flocks by

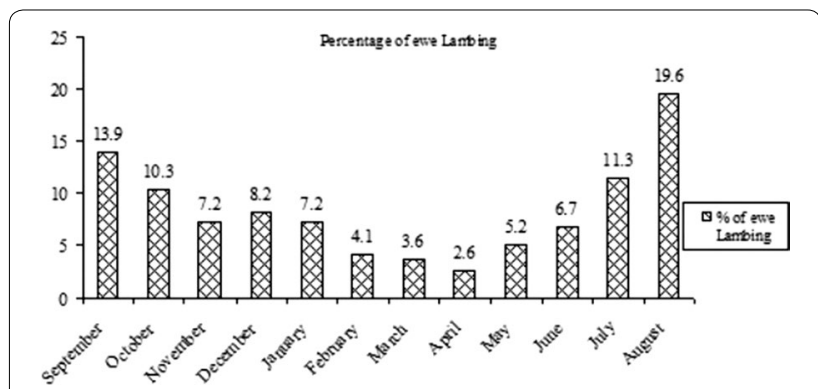

Fig. 2 Lambing distribution of Gumz ewes throughout the year

Table 2 Phenotypic standard deviations $\left(\sigma_{\mathrm{p}}\right)$, economic values, heritabilities along diagonal, genetic (above diagonal) and phenotypic (below diagonal) correlations used in simulated selection in Menz sheep Source: [18]

\begin{tabular}{lllllr}
\hline Traits & Economic values (birr) & Variance & SWT & LTS & PWS \\
\hline SWT & 34.5 & 4.64 & 0.29 & 0.09 & 0.10 \\
LTS & 60.2 & 0.012 & 0.09 & 0.13 & -0.02 \\
PWS & 190.6 & 0.013 & 0.10 & 0.00 & 0.07 \\
\hline
\end{tabular}

SWT six-month weight, LTS litter size, PWS pre-weaning survival

stratified randomization technique using body weight. About $10 \%$ of best rams each year should be selected at nucleus flocks for own use. The second best rams will be distributed to flocks of smallholder farmers participating in the breeding strategy project.

\section{Input parameters for the breeding program}

Essential input parameters for running ZPLAN are presented in Table 1. Some of the parameters required for the designs were generated from the production system, own flock ranking and on-farm monitoring studies [7, 9, 14].

\section{Genetic and phenotypic parameters}

The phenotypic standard deviations, the economic weight and the traits' heritabilities, genetic and phenotypic correlations are presented in Table 2 . Since the genetic parameters are lacking for the Gumz sheep breed, the parameters estimated for Menz sheep are used [18]. Relative economic weight for each trait was based on the program for which breeding plan was designed and computed by standardizing the values with the additive genetic standard deviation $\left(\sigma_{\mathrm{A}}\right)$ following the guidelines of FAO [19].

Evaluation of alternative breeding programs

Alternative breeding schemes were evaluated using the computer program ZPLAN [17]. Based on the population, biological and economic parameters, ZPLAN 
Table 3 Genetic gain per year in the breeding objective and its component traits achieved from selection using four alternative Gumz sheep breeding schemes

\begin{tabular}{llllll}
\hline & \multicolumn{2}{l}{$\begin{array}{l}\text { Village-based } \\
\text { schemes }\end{array}$} & & \multicolumn{2}{l}{$\begin{array}{l}\text { Central nucleus-based } \\
\text { scheme }\end{array}$} \\
\cline { 2 - 3 } \cline { 6 - 7 } & Scheme-1 & Scheme-2 & & Scheme-3 & Scheme-4 \\
\hline Breeding objective $^{\mathrm{a}}$ & 5.71 & 6.31 & & 12.29 & 12.37 \\
SWT (kg) & 0.154 & 0.171 & & 0.334 & 0.336 \\
LTS & 0.0017 & 0.0018 & & 0.0036 & 0.0036 \\
PWS & 0.0015 & 0.0016 & & 0.0029 & 0.0029 \\
\hline
\end{tabular}

a The annual monetary genetic gains for the breeding objective were calculated as a sum of the products of the respective genetic gains and economic weights of the component traits (SWT: six-month weight, MWT mature weight, LTS litter size and PWS pre-weaning survival)

calculates the annual genetic gain for the breeding objective, genetic gain for single traits and return of investment adjusted for costs (profit) using the gene flow method and selection index procedures.

\section{Results}

The annual monetary genetic gains of breeding-objectives traits are shown in Table 3 for the different breeding schemes. The result showed that the central nucleusbased schemes resulted in fastest genetic progress than those from village-based schemes. Monetary genetic gains of 12.29 and 12.37 for central nucleus-based schemes were predicted while the corresponding values for village-based schemes were 5.71 and 6.31 (Table 3). Monetary genetic gains for the central nucleus-based scheme in the breeding objective, which is the total gain from the three traits expressed in monetary units, were higher than the village-based schemes. This was because selection assumed accurate breeding values of the candidate rams, unlike in the village-based schemes where candidates were selected based on phenotypes. The highest genetic gain of $0.336 \mathrm{~kg}$ per year for 6 month's weight was predicted from a larger central nucleus-based scheme (scheme-4) but the profit was lower than the smaller central nucleus-based scheme (scheme-3) since the discounted costs of maintaining the larger nucleus flock were higher (15.89) than the smaller nucleus flock (7.94). Among the village-based schemes, the highest value of $0.171 \mathrm{~kg}$ annual genetic gain of the 6 -months weigh was simulated from scheme-2 whereas the lowest value of $0.154 \mathrm{~kg}$ was simulated from scheme- 1 . The results for the two village-based schemes showed that both the monetary genetic gains and profits were highest if most of the ewes (about 85\%) were synchronized to lamb in restricted months rather than throughout the year.
The lowest annual genetic gains of twining rate with the range of $0.0017-0.0036 \%$ were predicted from all schemes. Relatively lower annual genetic gains of 0.0017 and $0.0018 \%$ were predicted from scheme-1 and 2, respectively. The annual genetic gain of lamb survival at different schemes ranged from 0.0015 to $0.0029 \%$. Relatively higher annual genetic gain of $0.0029 \%$ survival rate was predicted from central nucleus-based schemes.

The annual returns, costs and profit per ewe of the population for different alternative schemes are presented in Table 4. The highest annual return of 64.97 Birr/ewe/year for scheme-4 was predicted from central nucleus-based scheme while the lowest 41.65 was obtained in scheme- 1 from village-based schemes (Table 4). The annual costs were calculated per ewe in the whole population. These costs were higher for village-based schemes than central nucleus-based schemes. This is because the cost for the central nucleus-based scheme was distributed throughout the whole population of about 7200 ewes. The profit/ ewe/year was in the range of 18.51 Birr in scheme-1 to 49.08 Birr in scheme-4. Among the village-based schemes, scheme- 2 was the profitable design but it was less profitable compared to the central nucleus-based schemes. Scheme-3 was more profitable (50.57 Birr/ewe) than the other central nucleus-based scheme (scheme-3).

\section{Discussion}

All scenarios simulated as alternatives had advantages in terms of genetic gain and profit. Results show that a slow genetic progress was obtained in village-based scheme with existing lambing distribution over a year (scheme-1) compared to village-based scheme with improved lambing distribution (scheme-2). This was because only few selection candidates would be available in each round of selection due to dispersed lambing resulting in low selection intensity and thus slow genetic progress. A study in the Ethiopian highlands [20] also reported that yearround distributed lambing could have implication in

Table 4 Returns, costs and profits per ewe per year (Birr) obtained from selection in Gumz sheep using four alternative breeding schemes

\begin{tabular}{llllll}
\hline & \multicolumn{2}{l}{$\begin{array}{l}\text { Village-based } \\
\text { schemes }\end{array}$} & \multicolumn{2}{l}{$\begin{array}{l}\text { Central nucleus-based } \\
\text { scheme }\end{array}$} \\
\cline { 2 - 3 } \cline { 5 - 6 } \cline { 5 - 6 } & Scheme-1 & Scheme-2 & & Scheme-3 & Scheme-4 \\
\hline Return/ewe/year & 41.65 & 46.03 & & 58.52 & 64.97 \\
Cost/ewe/year & 23.10 & 23.14 & & 7.94 & 15.89 \\
Fixed costs per ewe & 11.27 & 11.27 & & 7.38 & 14.77 \\
Variable costs & 11.83 & 11.87 & & 0.56 & 1.12 \\
Profit/ewe/year & 18.51 & 22.88 & & 50.57 & 49.08
\end{tabular}


genetic improvement and flock productivity. This is due to the dispersed lambing and small number of candidates which lead to lower selection intensity and hence slow genetic progress.

Village-based scheme with estrous synchronization could be another alternative for achieving concentrated lambing with a short period of time. Estrous synchronization would help to increase the number of lambs and help in adjusting lambing time to a better season [20]. Currently, introduction of estrous synchronization and artificial insemination (AI) in village flocks has been suggested for achieving planned and concentrated lambing $[21,22]$. In the present study, faster genetic progress and profit from village-based scheme was predicted through improved breeding management and estrous synchronization. Similarly, a previous study on mature Merino ewes [23] reported 54.32\% lambing rate over natural synchronized lambing after cervical artificial insemination following a progestagen (MAP)-PMSG (375IU) treatment. In these scenarios, higher selection intensity is exploited to result in higher predicted annual genetic gain and profit. Another study [20] also reported that estrous synchronization had $17.1-25.2 \%$ more lambing over natural synchronized lambing. The advantage of estrous synchronization over selection under natural estrous synchronization was also given 160.5-190.1\% more profit [20]. Estrous responses to hormonal synchronization ranging from 55 to $93.2 \%$ have been reported for Ethiopian sheep breeds [24, 25]. A review [26] of estrous responses in Nigerian goat breeds showed a range from 20 to $100 \%$ success.

The genetic gain in 6-month weights in village-based scheme with improved lambing distribution was highest compared to village-based schemes with existing lambing distribution over a year (Table 3). By improving breeding management and introducing estrous synchronization into the current breeding practices, genetic gains and profits from scheme- 2 were relatively higher than those from scheme-1. This implies that village-based scheme with improved lambing (scheme-2) is a better alternative breeding scenario to scheme- 1 in the villagebased breeding programs. The predicted genetic gain in 6-month weight ranged from 0.154 to $0.171 \mathrm{~kg}$. These values were found in the ranges of genetic gain of 0.120 to $0.179 \mathrm{~kg}$ in 6-month weight of Menz sheep [21]. The genetic gain of 6-month weight predicted in this study is lower than the range of the predicted annual genetic gain of 6-month weight of western lowland and Abergelle goats [27].

Very low genetic gains of twining rate were predicted from all alternatives ranging from 0.0017 to $0.0036 \%$. The differences of genetic gain of litter size between different alternatives were very small. The genetic gains of lamb survival at different scenarios ranged from 0.0015 to $0.0029 \%$. The present study revealed that genetic progress in litter size and lamb survival was low and comparable among village-based schemes and central nucleus-based schemes. Compared to the current study, lowest genetic gain results for lamb survival with the range of $0.009-0.01 \%$ were predicted for Ethiopian Afar sheep breed [28]. The low genetic gain in reproductive traits is attributed to their low heritability and genetic correlations with growth traits [28-30] in the breeding objective.

The central nucleus-based scheme with $10 \%$ nucleus size (scheme-4) had most efficient genetic gain compared to central nucleus-based scheme with $5 \%$ nucleus size (scheme-3), but it was less profitable. The highest genetic gain in 6-month weigh was obtained from scheme-4, as scheme-4 benefited from higher selection intensity compared to scheme-3. Similarly, previous study [31] reported that applying higher selection intensity would result in even higher genetic gain on the one hand and higher discounted returns on the other hand. The predicted genetic gain in 6-month weight $(0.336 \mathrm{~kg})$ of central nucleus-based scheme was comparable to those of $[15,32]$ who reported 0.29 and $0.34 \mathrm{~kg}$ genetic progress, respectively, in 6-month weight of nucleus flocks of Menz sheep. Comparison of central nucleus-based schemes and village-based schemes showed that a highest genetic gain was predicted from central nucleus-based schemes. The study by [30] also noted that central nucleus-based scheme with selection on breeding values had an advantage over a village-based scheme where selection was on candidates' phenotypes. The central nucleus-based scheme was also highest in profit compared to the village-based schemes. However, some central nucleusbased breeding programs have failed under smallholder production systems [33, 34]. The failure of central nucleus-based breeding programs could be due to technical limitations, absence of infrastructures to support the breeding programs [1].

\section{Conclusion}

The central nucleus-based scheme resulted in the highest genetic gain and economic efficiencies compared to village-based schemes. However, this scheme requires establishing a large central nucleus flocks. Running such a large nucleus flock may not be sustainable due to the long-term financial support and commitment required. Village-based scheme is the best alternative breeding scenario that needs to be optimized for genetic improvement in Gumz sheep. This study result suggested scheme-2 (village-based scheme with estrous synchronization) is 
better than scheme-1. The possibility of introducing hormonal estrous synchronization in village flocks is promising, as the results indicate effectiveness of the technology.

\section{Abbrevaitions}

Al: artificial insemination; ARARI: Amhara Agricultural Research Institutes; LTS: litter size; PMSG: pregnant mare serum gonadotropin; PWS: pre-weaning lamb survival; SWT: six-month weight.

\section{Authors' contributions}

YD and SG collected, analyzed and interpreted the data. SG, MU and YT helped to draft the manuscript. All authors read and approved the final manuscript.

\section{Author details}

1 Department of Animal and Range Sciences, College of Agriculture, Bule Hora University, PO Box 144, Bule Hora, Ethiopia. ${ }^{2}$ School of Animal and Range Sciences, College of Agriculture and Environmental Science, Haramaya University, PO Box 138, Dire Dawa, Ethiopia. ${ }^{3}$ Herd Health, Livestock Expert, International Livestock Research Institute, PO Box 5689, Addis Ababa, Ethiopia.

\section{Acknowledgements}

I would like to thank Ministry of Education (MOE) for the scholarship and financial support. I am very grateful to all assistances, knowledge and experiences we have received from the farmers in Metema and Quara districts.

\section{Competing interests}

The authors declare that they have no competing interests.

\section{Availability of data and materials}

We declare that the data and materials presented in this manuscript can be made available as per the editorial policy of the journal.

\section{Consent for publication}

Not applicable.

\section{Ethics approval and consent to participate}

Not applicable to this manuscript.

\section{Funding}

This research was conducted with the financial support of Ethiopian Ministry of Education (MOE).

\section{Publisher's Note}

Springer Nature remains neutral with regard to jurisdictional claims in published maps and institutional affiliations.

\section{Received: 3 October 2017 Accepted: 26 February 2018}

Published online: 21 May 2018

\section{References}

1. Kosgey IS, Baker HMJ, Udod JAM. Successes and failures of small ruminant breeding programmes in the tropics: a review. Small Ruminat Res. 2006;61:13-28.

2. Getachew T, Haile A, Tibbo M, Sharma AK, Sölkner J. Herd management and breeding practices of sheep owners in a mixed crop-livestock and a pastoral system of Ethiopia". Afr J Agric Res. 2010;5(8):685-91.

3. Haile A, Wurzinger M, Mueller J, Mirkena T, Duguma G, Mwai MA, Sölkner J, Rischkowsky B. Guidelines for setting up community-based sheep breeding programs in Ethiopia. 2011.

4. Edea Z, Haile A, Tibbo M, Sharma AK, Sölknerand J, Wurzinger M. Sheep production systems and breeding practices of smallholders in western and south-western Ethiopia: implications for designing communitybased breeding strategies. Livest Res Rural Dev. 2012;24:7.

5. Gizaw S. Sheep resources of Ethiopia: genetic diversity and breeding strategy. Ph.D. thesis, Wageningen University, Netherlands; 2008.
6. Mulugeta E, Gebremedhin B, Hoekstra D. Analysis of the Ethio-Sudan Cross-Border Cattle Trade. IPMS (improving productivity and market success) of Ethiopian farmers project working paper 2. ILRI (International Livestock Research Institute), Nairobi, Kenya; 2007.

7. Abegaz S, Hegde BP, Taye M. Growth and physical body characteristics of Gumuz sheep under traditional management systems in Amhara Regional State, Ethiopia". Livest Res Rural Dev. 2011;23:1-5.

8. Lemma S. Phenotypic characterization of indigenous sheep breeds in the Amhara national regional state of Ethiopia. M.Sc. thesis, Haramaya University, Ethiopia; 2009

9. Dagnew Y, Urge M, Tadesse Y, Gizaw S. Growth performance of Gumz, Rutana and Gumz-Rutana crossbred sheep under on-farm conditions in north western lowlands of Amhara, Ethiopia. East Afr J Vet Anim Sci. 2017:2(1):1-13.

10. Gizaw S, Getachew T, Edea Z, Mirkena T, Duguma G, Tibbo M, Rischkowsky, B., Mwai, O., Dessie T, Wurzinger, M., Solkner, J and Haile A. Characterization of indigenous breeding strategies of the sheep farming communities of Ethiopia. A basis for designing community-based breeding programs. International Center for Agricultural Research in the Dry Areas (ICARDA); 2013.40 pp.

11. Hiemstra SJ, Drucker AG, Tvedt M, Louwaars N, Oldenbroek JK, Awgichew K, Abegaz S, Bhat PN. What's on the menu? Options for strengthening the policy and regulatory framework for the exchange, use and conservation of animal genetic resources. Anim Genet Resour. 2007;4(3):65-74.

12. Desalew T, Tegegne A, Nigatu L. Rangeland Condition and feed resources in Metema District, North Gondar Zone, Amhara Region, Ethiopia. IPMS (improving productivity and market success) of Ethiopian farmers project working paper 25. Nairobi, Kenya, ILRI; 2010.

13. Habtamu T, Bekele A. Habitat association of insectivores and rodents of Alatish National Park, northwestern Ethiopia. Trop. Ecol. 2008;49:1-11.

14. Dagnew $Y$, Urge M, Tadesse $Y$, Gizaw S. Sheep production and breeding systems in north western lowlands of Amhara region, Ethiopia: implication for conservation and improvement of Gumz sheep breed. Open J Anim Sci. 2017;7(2):179-97.

15. Gizaw S, van Arendonk JAM, Valle-Zárate A, Haile A, Rischkowsky B, Dessie T, Okeyo AM. Breeding programs for smallholder sheep farming systems: I. Evaluation of alternative designs of breeding schemes. J Anim Breed Genet. 2014;131(5):341-9.

16. Wuletawu Z, Ayalewu W, Solkiner J. Breeding scheme based on analysis of community breeding objectives for cattle in north-western Ethiopia. Ethiop J Anim Prod. 2006;6(2):53-66.

17. Willam A, Nitter G, Bartenchlager $H$, Karras $K$, Niebel E. ZPLAN mannual for a PC-program to optimize livestock selection schemes. Stuttgart: Institute of Animal Production in the Tropics and Subtropics. Universität Hohenheim; 2008.

18. Gizaw S, Joshi BK. Estimates of genetic parameters for growth traits in Menz and Awassi x Menz crossbred sheep in Ethiopia. Indian J. Anim. Sci. 2004;74(8):864-7

19. FAO. Breeding strategies for sustainable management of animal genetic resources. FAO animal production and health guidelines. No. 3. Rome; 2010.

20. Gizaw S, Tesfay Y, Mekasha Y, Mekuriaw Z, Gugsa T, Ebro A, Gebremedhin B, Hoekstra D. Hormonal oestrus synchronization in four sheep breeds in Ethiopia: impacts on genetic improvement and flock productivity. LIVES working paper 25. Nairobi, Kenya: International Livestock Research Institute (ILRI); 2016.

21. Galukande EH, Mulindwa H, Wurzinger M, Roschinsky R, Mwai O. Crossbreeding cattle for milk production in the tropics: achievements, challenges and opportunities. J Anim Genet Resour. 2013;52:111-25.

22. Getachew T, Haile A, Wurzinger M, Rischkowsky B, Gizaw S, Abebe A. Review of sheep crossbreeding based on exotic sire and among indigenous breeds in the tropics: an Ethiopian perspective. Afr J Agric Res. 2016;11(11):901-11.

23. Simonett $L$, Ramos G, Gardon JC. Effect of estrus synchronization and artificial insemination on reproductive performance of Merino sheep. Braz J Vet Res Anim Sci. 2002;39(3):143-6.

24. Mekuriaw $Z$. Effect of time of pregnant mare serum gonadotrophin administration on oestrus synchronization efficiency and fertility in blackhead ogaden ewes, Ethiop. J Anim Prod. 2009;9:135-45. 
25. Mekuriaw Z, Assefa H, Tegegne A, Muluneh D. Estrus response and fertility of Menz and crossbred ewes to single prostaglandin injection protocol. Trop Anim Health Prod. 2016;8(1):53-7.

26. Omontese BO, Rekwot PI, Ate IU, Ayo JO, Kawu MU, Rwuaan JS, Nwannenna Al, Mustapha RA, Bello AA. An update on oestrus synchronisation of goats in Nigeria. Asian Pac J Reprod. 2016;5(2):96-101.

27. Abegaz S, Sölkner J, Gizaw S, Dessie T, Haile A, Mirkena T, Getachew T, Wurzinger M. Optimizing alternative schemes of community-based breeding programs for two Ethiopian goat breeds. Acta Agrar Kaposváriensis. 2014;18(1):47-55.

28. Mirkena T, Duguma G, Willam A, Wurzinger M, Haile A, Rischkowsky B, Okeyo MA, Tibbo M, Sölkner J. Community-based alternative breeding plans for indigenous sheep breeds in four agro-ecological zones of Ethiopia. J Anim Breed Genet. 2012;129:244-53.

29. Safari E, Fogarty NM, Gilmour AR. A review of genetic parameter estimates for wool, growth, meat and reproduction traits in sheep. Livest Prod Sci. 2005;92:271-89.

30. Gizaw S, Rischkowsky B, Valle-Zarate A, Haile A, Van Arendonk JAM, Okeyo AM, Dessie T. Breeding programs for smallholder sheep farming systems:
I. Evaluation of alternative designs of breeding schemes. J Anim Breed Genet. 2014;131:341-9.

31. Jembere T, Kefelegn K, Rischkowsky B, Haile A, Okeyo MA, Dessie T. Recording birth weight has no significance in village based genetic improvement programs of small ruminants. Livest. Res. Rural Dev. 2016;28:8.

32. Gizaw S, Lemma S, Komen H, van Arendonk JAM. Breeding programmes for smallholder sheep farming systems: II. Optimization of cooperative village breeding schemes. J Anim Breed Genet. 2007;14:1-8.

33. Kosgey IS, Van Arendonk JAM, Baker RL. Economic values for traits in breeding objectives for sheep in the tropics: impact of tangible and intangible benefits. Livest Prod Sci. 2004;88(1-2):143-60.

34. Singh SK, Singh MK, Rai B. Evaluation of different goat production systems in India and breeding strategy for improvement. In: Proceeding of eighth national conference on animal genetics and breeding; national livestock breeding policy, 8-10 March 2005, Central Institute for Research on Goats, Makhdoom, Farah-281 122, Mathrua (UP) India.
Ready to submit your research? Choose BMC and benefit from:

- fast, convenient online submission

- thorough peer review by experienced researchers in your field

- rapid publication on acceptance

- support for research data, including large and complex data types

- gold Open Access which fosters wider collaboration and increased citations

- maximum visibility for your research: over $100 \mathrm{M}$ website views per year

At BMC, research is always in progress.

Learn more biomedcentral.com/submissions 